\title{
Potential role of sponge communities in controlling phytoplankton blooms in Florida Bay
}

\author{
Bradley J. Peterson ${ }^{1, *}$, Charles M. Chester ${ }^{2}$, Frank J. Jochem ${ }^{3}$, \\ James W. Fourqurean ${ }^{3,4}$ \\ ${ }^{1}$ Marine Sciences Research Center, Stony Brook University, 239 Montauk Highway, Southampton, New York 11968, USA
${ }^{2}$ Division of Sciences, Spring Hill College, 4000 Dauphin Street, Mobile, Alabama 36608, USA
${ }^{3}$ Department of Biological Sciences and ${ }^{4}$ Southeast Environmental Research Center, Florida International University,
University Park, Miami, Florida 33199, USA
}

\begin{abstract}
An unprecedented series of ecological disturbances have been recurring within Florida Bay since the summer of 1987. Persistent and widespread phytoplankton and cyanobacteria blooms have coincided with the large scale decimation of sponge communities. One hypothesis is that the large scale loss of suspension-feeding sponges has rendered the Florida Bay ecosystem susceptible to these recurring blooms. The primary objective of this study was to experimentally evaluate the potential for suspension-feeding sponges to control nuisance phytoplankton blooms within Florida Bay prior to a large sponge die-off event. To achieve this objective, we determined the extent and biomass of the surviving sponge community in the different basins of Florida Bay. Many areas within Florida Bay possessed sponge densities and biomasses of 1 to 3 ind. $\mathrm{m}^{-2}$ or 100 to $300 \mathrm{~g} \mathrm{~m}^{-2}$ respectively. The dominant species included Spheciospongia vesparia, Chondrilla nucula, Cinachyra alloclada, Tedania ignis and Ircinia sp., which accounted for $68 \%$ of individual sponges observed and $88 \%$ of sponge biomass. Laboratory grazing rates of these dominant sponges were experimentally determined on 4 different algal food treatments: a monoculture of cyanobacteria Synechococcus elongatus, a monoculture of the diatom Cyclotella choctawhatcheeana, a monoculture of the dinoflagellate Prorocentrum hoffmanianum, and an equal volume of the 3 monocultures combined. To estimate the impact of a mass sponge mortality event on the system-wide filtration rate of Florida Bay, we combined estimates of the current sponge biomass and laboratory sponge filtration rates with estimates of mean volumes of the sub-basins of Florida Bay. This study implies that the current blooms occurring within the central region of Florida Bay can be explained by the loss of the dominant suspension feeder in this system, and there is no need to invoke a new addition of nutrients within this region for the blooms to occur.
\end{abstract}

KEY WORDS: Sponges $\cdot$ Phytoplankton blooms $\cdot$ Benthic grazing $\cdot$ Florida Bay Resale or republication not permitted without written consent of the publisher

\section{INTRODUCTION}

Florida Bay, the largest estuary in Florida (USA), has historically served as a landscape of diverse habitats that provide a nursery for a wide range of commercially and recreationally important fish and invertebrate species. An unprecedented series of ecological disturbances has recurred within Florida Bay since the summer of 1987 (Boesch et al. 1993, Fourqurean \& Robblee 1999), which in all likelihood has reduced the productivity of this vast ecosystem. One dramatic effect of these disturbances has been the widespread mortality of turtlegrass Thalassia testudinum. Although the direct cause of this massive loss was likely sulfide toxicity (Borum et al. 2005), it has been hypothesized that the cumulative impact of a number of stress-inducing factors contributed to this phenomenon (Robblee \& DiDomenico 1991). Indirect eutrophication from decomposing seagrass, increased turbidity resulting from the concomitant algal blooms, and the 
loss of sediment stability provided by the seagrass further exacerbated the deterioration of the Florida Bay ecosystem. This was evidenced by persistent and widespread phytoplankton and cyanobacteria (Synechococcus spp.) blooms, which were indirectly responsible for a continued decline of remaining seagrass communities via increased light attenuation.

Coincident with these blooms was the large scale decimation of sponge communities (Butler et al. 1994, Butler et al. 1995, Stevely \& Sweat 1998). Nearly every species of sponge was impacted and over $90 \%$ of the sponges were killed or damaged in many areas (Butler et al. 1995). Unfortunately, the precise agent of mortality remains unknown. Previous instances of mass sponge mortalities off the coast of central Florida, the Bahamas, and the Mediterranean were attributed to a variety of infections (Peters 1993), usually activated by deleterious environmental conditions such as low salinity, abnormal temperature, organic pollution, or heavy sedimentation. Previous reports of sponge mass mortality have not been associated with blooms of planktonic cyanobacteria, such as Synechococcus spp., which can be toxic to marine animals (Mitsui et al. 1989). In Florida Bay, unusual mortality of fish or invertebrates that might suggest the occurrence of a toxic or hypoxic bloom was not witnessed (Butler et al. 1995).

Blooms swept over extensive portions of the bay north of the middle Keys after the initial seagrass die-off and persisted for months at a time (Phlips et al. 1999). The proliferation of Synechococcus spp. and the diatom Rhizosolenia spp. blooms in the only region of continental USA that contains sensitive coral reef ecosystems has caused widespread concern among scientists and water managers. Some regions of Florida Bay exhibit high levels of algal and/or non-algal suspended solids, resulting in low light penetration. In one study, average chlorophyll a (chl a) concentrations of $\sim 20 \mu \mathrm{g} \mathrm{l}^{-1}$ were observed in north-central regions of the bay, with individual values exceeding $40 \mu \mathrm{g} \mathrm{l}^{-1}$, whereas average concentrations in the north-eastern regions were below $2 \mu \mathrm{g} \mathrm{l}^{-1}$ (Phlips \& Badylak 1996, Phlips et al. 1999). High concentrations of chlorophyll indicate a potentially significant role of phytoplankton in light attenuation for certain regions of the bay. One hypothesis suggests that the susceptibility of Florida Bay to these recurring phytoplankton blooms is due to the large scale loss of filter feeding sponges (Lynch \& Phlips 2000).

When abundant, sponges are a particularly dominant structural feature of the Florida Bay seagrass and hard-bottom habitats, functioning as efficient filters of small $(<5 \mu \mathrm{m})$ and large planktonic particles (Reiswig 1971, van de Vyver et al. 1990, Lynch \& Phlips 2000). Previous studies elsewhere have illustrated that the grazing pressure of filter feeding bivalves may control phytoplankton abundance (Officer et al. 1982, Doering
\& Oviatt 1986, Dame et al. 1991). These studies have generated great interest in the role that filter feeding bivalves have on phytoplankton growth and biomass; however, few have evaluated the influence that historically high densities of sponges may have had on phytoplankton biomass (Pile et al. 1997).

The potential for sponges to affect phytoplankton growth dynamics may be great. These organisms filter large volumes of water (up to $1 \mathrm{l} \mathrm{h}^{-1}$ per $\mathrm{cm}^{3}$ of body volume [Reiswig 1971]), with retention efficiencies between 75 and $99 \%$ (Pile et al. 1996). Studies have shown that the grazing rates of some sponges are within the same range (29 to $1970 \mathrm{mg} \mathrm{C} \mathrm{m}^{-2} \mathrm{~d}^{-1}$ [Pile et al. 1997]) as filter feeding bivalves (9 to $3621 \mathrm{mg} \mathrm{C} \mathrm{m}^{-2} \mathrm{~d}^{-1}$ [Griffiths \& Griffiths 1987]). In addition, freshwater studies have recently demonstrated that the sponge communities within the littoral zone of Lake Baikal, Russia, can create a layer of picoplankton-depleted water overlying the benthic community (Pile et al. 1997), suggesting that abundant sponge populations may exert an important grazing impact on their habitat.

The recent (1998) abundance of sponges in Florida Bay remains a fraction of its former (1991) abundance in some areas. The 2 sponge species (Spheciospongia vesparia and Ircinia campana) that accounted for a dominant portion (69\%) of total sponge community biomass prior to the die-offs have exhibited either slow (S. vesparia) or essentially no (I. campana) recovery, with speculations that restoration of these species may take 5 to $10 \mathrm{yr}$ or longer, especially in the case of I. campana (Stevely \& Sweat 1998). It is clear from this study and that of Butler et al. (1995) that the severely decimated sponge community within Florida Bay has yet to recover.

Some investigators have suggested that a new source of nitrogen or phosphorus is fueling the elevated phytoplankton biomasses observed over the last decade in the north-central basins of Florida Bay (Lapointe 2004). An alternative hypothesis is that the loss of the dominant suspension feeding grazer (i.e. sponges) from this area of Florida Bay has rendered a system-wide trophic dysfunction, resulting in the initiation and great magnitude of the phytoplankton blooms. Furthermore, the proliferation of phytoplankton blooms in the north-central region of Florida Bay may have contributed to the reduction in light available to benthic plant production. If the presence of sponges reduces phytoplankton biomass, then sponges may have a great impact on decreasing the shading effects of these blooms, and the loss of these organisms may have cascading effects on the associated benthic plant communities within Florida Bay.

The primary objective of this study was to experimentally determine the potential for suspension feeding sponges to reduce phytoplankton biomass and 
enhance water column clarity in Florida Bay. Specifically, we addressed the following questions. (1) What is the current biomass of the sponge community across Florida Bay? (2) What are the filtration and grazing rates of the surviving dominant sponge species on the bloom-forming phytoplankton and cyanobacteria of Florida Bay? (3) Is it possible that the loss of the sponge community can account for the recurring phytoplankton blooms in the north-central region of Florida Bay?

\section{MATERIALS AND METHODS}

Study site. Florida Bay (ca. $25^{\circ} 05^{\prime} \mathrm{N}, 81^{\circ} 45^{\prime} \mathrm{W}$ ) is a shallow embayment $(<2 \mathrm{~m}$ ) located south of the Florida peninsula and west of the Florida Keys (Fig. 1). It is compartmentalized into $\sim 45$ separate basins by a series of carbonate mud banks, which restrict circulation within the bay. Tidal energy is quickly attenuated by these banks, preventing a lunar tide for most of central and north-eastern Florida Bay. The bay receives about $1.2 \mathrm{~m}$ of rain a year, with roughly $75 \%$ of the precipitation falling in the wet season (May to October) with an equal magnitude of evaporation occurring in the dry season. Mean annual water temperature is $24.5^{\circ} \mathrm{C}$, with a mean monthly temperature of $20^{\circ} \mathrm{C}$ in January and $28^{\circ} \mathrm{C}$ in August. The water column in Florida Bay is generally oligotrophic, and phytoplankton biomass has historically been quite low throughout the system. There is a strong phosphorus limitation of phytoplankton in Florida Bay (Fourqurean et al. 1993); however, other resources (e.g. light, nitrogen, silica) may also be important in controlling plankton biomass in some areas of the bay (Lavrentyev et al. 1998). Dissolved inorganic phosphorus (DIP) concentrations are near detection limits $(20 \mathrm{nM})$, whereas dissolved inorganic

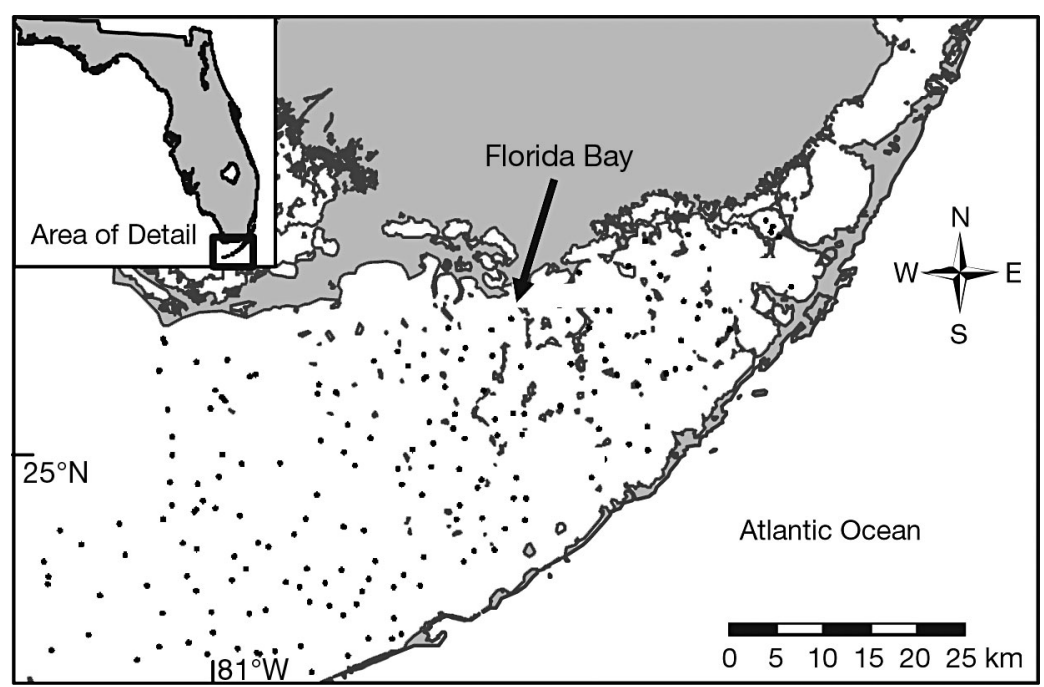

Fig. 1. Florida Bay, showing surveys of sponge communities (207 sites, •) nitrogen (DIN) concentrations can be relatively high (median value $3.3 \mu \mathrm{M}$, but concentrations $>10 \mu \mathrm{M}$ are not uncommon) and are dominated by ammonium (Fourqurean et al. 1993). Water quality characteristics have been used to subdivide Florida Bay into 3 major zones: (1) a western zone of relatively stable marine conditions and near-Redfield seston N:P ratios, (2) a central zone with a tendency towards hypersalinity $>40$ ppt, high seston $\mathrm{N}: \mathrm{P}$, and high concentrations of dissolved organic matter, and (3) an eastern zone with highly variable salinity, generally high concentrations of DIN and very high seston N:P (Boyer et al. 1997).

Field surveys of sponge abundance. A stratified random sampling method, hexagonal tessellation, was used to identify 207 sites across the boundaries of Florida Bay (Fig. 1). This assured reasonably uniform coverage while adhering to the random distribution requirements for statistical testing. All sites were examined between May and September 2001. At each site, a $50 \mathrm{~m}$ transect was extended to the north. All sponges within $0.5 \mathrm{~m}$ of the transect tape (on either side) were identified and counted. In addition, at 10 pre-selected random points along the transect a $0.5 \mathrm{~m}^{2}$ quadrat was placed on the sediment surface and all sponge biomass within the quadrat was removed, taken to the laboratory and freeze-dried to a constant weight $( \pm 5 \mathrm{mg})$. Morphometric measurements (diameter, height, and circumference) were taken for large individuals of Speciospongia vesparia without removal.

Laboratory grazing experiment. A laboratory grazing experiment was conducted to estimate the filtration rates of the dominant sponge species identified in the field survey: Spheciospongia vesparia, with an average individual volume of $1160 \mathrm{ml}$ and biomass of $239 \mathrm{~g}$ dry wt; Ircinia sp., $584 \mathrm{ml}$ and $62 \mathrm{~g}$ dry wt; Tedania ignis, $382 \mathrm{ml}$ and $30 \mathrm{~g}$ dry wt.; Cinachyra alloclada, $34 \mathrm{ml}$ and $5 \mathrm{~g}$ dry wt; and Chondrilla nucula, $4 \mathrm{ml}$ and $0.4 \mathrm{~g}$ dry wt. The sponge volumes and biomasses used in this experiment represent mean size of the corresponding species in the field. Filtration rate was measured as the volume of water cleared per unit time from a continuous monoculture of the cyanobacteria Synechococcus elongatus, a monoculture of the diatom Cyclotella choctawhatcheeana, a monoculture of the dinoflagellate Prorocentrum hoffmanianum, and an equal volume of the 3 monocultures combined. These 3 phytoplankton species represent a common cyanobacteria, diatom and dinoflagellate found within Florida Bay. The cultures were isolated from naturally 
occurring phytoplankton resident within Florida Bay by the Florida Marine Research Institute. Cells with a mean diameter of approximately $6.3 \mu \mathrm{m}$ are retained by sponges with $100 \%$ efficiency (Reiswig 1971). Therefore, a priori one might expect higher grazing rates to be achieved by the sponges for the diatom and dinoflagellate based on their cell sizes. Sponges from hard-bottom and seagrass habitats within Florida Bay were detached from the substrate and attached to individual bricks with zip ties. These sponges were allowed to recover and attach themselves onto the bricks in a re-circulating seawater tank. After a 2 wk period, those individuals that had successfully attached themselves were used for the grazing experiment.

Prior to each grazing experiment, 4 untested individual sponges were placed in separate 251 chambers or 11 beakers, depending on the sponge species size. Each chamber or beaker contained aerated seawater in which the sponges were allowed to acclimate for $30 \mathrm{~min}$; constant aeration of the chambers assured that the cultures remained well-mixed. Phytoplankton cultures achieved initial chl a concentrations between 300 and $600 \mu \mathrm{g} \mathrm{l}^{-1}$ or cell concentrations between 800000 to 1000000 cells $\mathrm{ml}^{-1}$. The reduction in phytoplankton biomass as a function of time was determined by removing water samples from each chamber after $0 \mathrm{~min}, 30 \mathrm{~min}, 1$, 2, 3 and $4 \mathrm{~h}$. Three replicate chambers or beakers with the phytoplankton but without a sponge colony served as the control treatment. Chl a concentrations, determined by collecting $60 \mathrm{ml}$ of water that was then filtered through a $25 \mathrm{~mm} \mathrm{GF/F}$ glass fiber filter, were used as a proxy for phytoplankton biomass. The filters were frozen for $24 \mathrm{~h}$ and then placed in $2.0 \mathrm{ml}$ spectrophotometric grade acetone in capped vials and stored in the freezer. Acetone extractions were continued for $48 \mathrm{~h}$ before chl a content was determined fluorometrically.

Changes in cell concentrations over time were quantified by flow cytometry, which also allowed the discrimination of species-specific particle size preferences among the dominant members of the sponge community. Subsamples of $2 \mathrm{ml}$ taken at the time points listed above were fixed with $1 \%$ buffered formalin and shock-frozen in liquid nitrogen. Thawed samples were measured at a flow rate of $1 \mu \mathrm{s}^{-1}$ on a Becton-Dickinson FACSort flow cytometer. Algal populations were discriminated based on their specific light scatter (a proxy of cell size), and chlorophyll autofluorescence signals recorded on 4 decades log scales. Cytometric data were analyzed by Win MDI 2.6, and cell concentrations calculated from measurement times based on weight-calibration of the flow rate.

Filtration rate was determined by the exponential reduction in algal cell concentration as a function of time using the formula: filtration rate $=\left(V_{\mathrm{sw}} \times t^{-1}\right) \times$ $\ln \left(C_{0} \times C_{t}^{-1}\right)$, where $V_{\mathrm{sw}}=$ volume of the container, $t=$ length of the grazing experiment ( $\mathrm{min}$ ), and $C_{0}$ and $C_{t}=$ algal concentrations at time 0 and time $t$, respectively. The reduction in cell concentration was plotted, and samples collected after any food limitation were not used in our calculations of filtration rate (Fig. 2).

In situ grazing experiment. In conjunction with the laboratory estimates of grazing rates on pure cultures of potential prey, sponge-mediated fluxes of natural plankton assemblages were conducted for Spheciospongia vesparia in the field using $40 \mathrm{l}$ re-circulating bell chambers. Each chamber was placed over a single sponge or bare substrate (2 experimental chambers over sponges and 1 no-sponge control). Ambient seawater was circulated through the chambers, allowing the sponges to acclimate for $30 \mathrm{~min}$. After the acclimation period, the system was operated in a closed-flow mode for $3 \mathrm{~h}$. Water samples $(240 \mathrm{ml})$ were collected at time 0 and every 30 min thereafter for $3 \mathrm{~h}$. Grazing was calculated by the decrease in phytoplankton biomass (measured by chl a) as a function of time. At the conclusion of the experiment, the sponge colonies were removed from the sediment surface and freeze dried. A sponge biomass-filtration rate regression was constructed, and the experimentally-derived filtration rates obtained in the laboratory were compared to those determined in situ. While this method uses natural seawater under natural temperature and illumination, and considerably minimizes disturbance to study animals, it is still susceptible to container effects. The no-sponge control chamber was used to identify these effects and determine the necessary pump speed required to maintain phytoplankton in suspension.

\section{RESULTS}

\section{Field survey}

Sponges were present at 152 of the 207 sites surveyed within Florida Bay (Fig. 1), and population densities ranged from 0.02 to 22 ind. $\mathrm{m}^{-2}$. Sponge biomass was collected at 116 of the 207 sites, and ranged from 0.48 to $1443 \mathrm{~g} \mathrm{~m}^{-2}$ (Fig. 3). The survey demonstrated that sponges are ubiquitous throughout Florida Bay, with greatest densities and biomasses in the southern central and western regions (Figs. 3). At current abundances, many areas within Florida Bay exhibit sponge densities of 1 to 3 ind. $\mathrm{m}^{-2}$ or biomasses of 100 to $300 \mathrm{~g} \mathrm{~m}^{-2}$. The sponge community within Florida Bay was shown to be composed of 19 species: Aaptos sp., Adocia implexiformis, Anthosigmella varians, Biemna sp., Chondrilla nucula, Cinachyra alloclada, Dysidea ethera, Geodia 


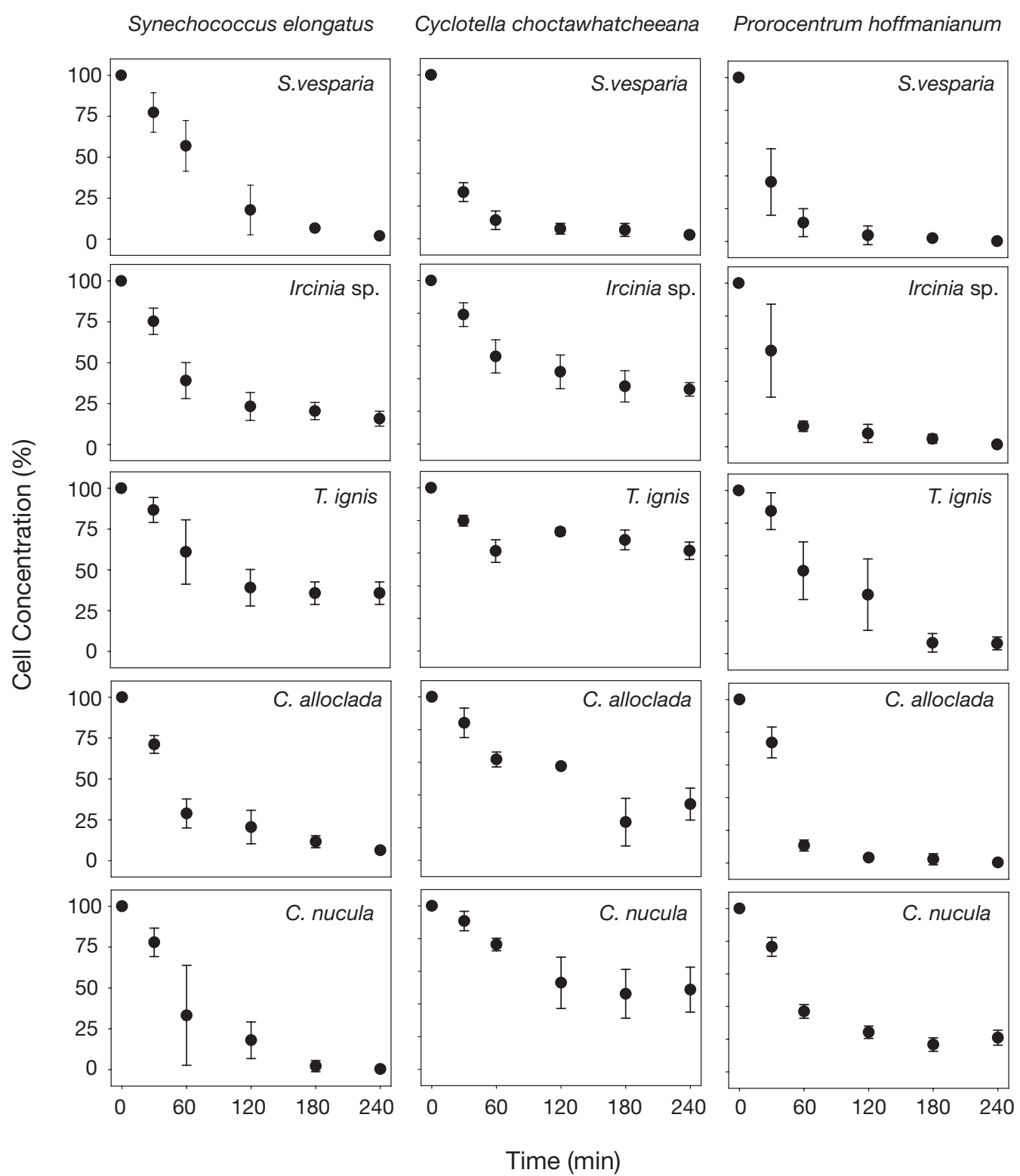

Fig. 2. Dominant sponges of Florida Bay. Change in particle concentration over time for replicate treatments in grazing experiments. Each column represent \% change in cells over duration of the grazing experiment for 5 sponges (Spheciospongia vesparia, Ircinia sp., Tedania ignis, Cinachyra alloclada, Chondrilla nucula) for each algal treatment (identified at top of each column). Error bars: SD

gibberosa, Haliclona sp., Hippospongia lachne, Hyrtios sp., Ircinia campana, Ircinia strobilina, Ircinia sp., Niphates erecta, Spheciospongia vesparia, Spongia barbara, Tedania ignis, Tethya crypta. The dominant species in density and biomass included Spheciospongia vesparia, Chondrilla nucula, Cinachyra alloclada, Tedania ignis, and Ircinia sp., which accounted for $68.2 \%$ of the individual sponges observed or $87.9 \%$ of the sponge biomass. Although sponge abundance and biomass varied considerably throughout Florida Bay, sponges were found over large portions of the bay and represented the dominant suspension feeding organism observed in our field surveys.

\section{Laboratory grazing experiment}

Filtration rates varied among and within sponge species for the different phytoplankton treatments (Table $1 \&$ Fig. 4). A $5 \times 4$ Model I ANOVA of grazing rates, with sponge species and algal food type as the 


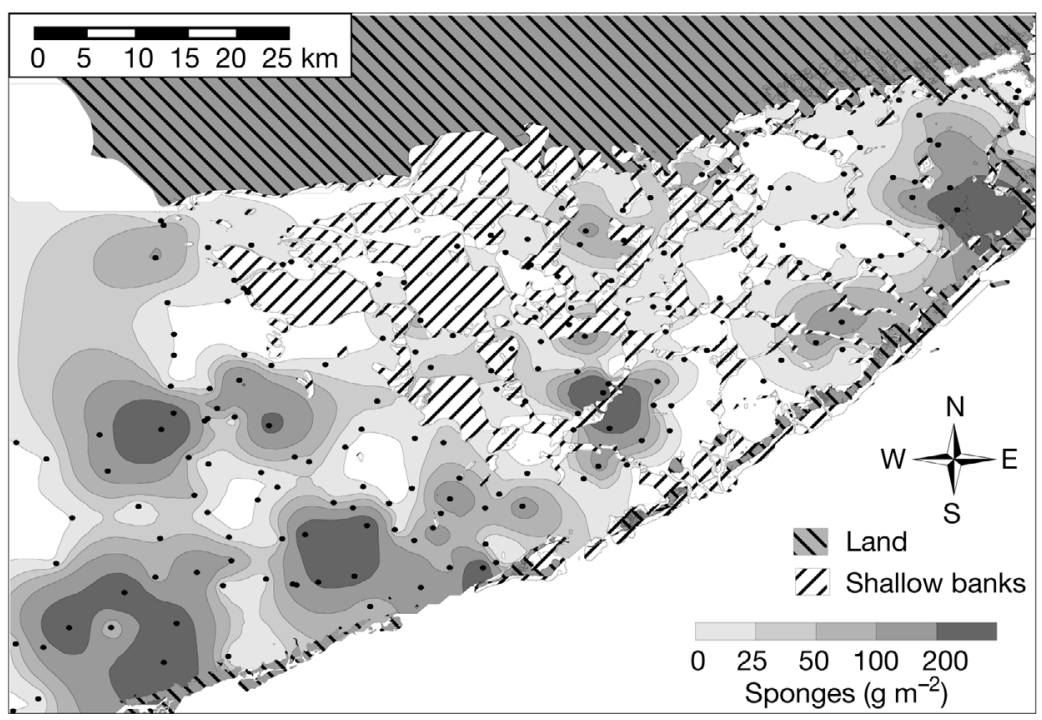

Fig. 3. Spatial plot of surviving sponge biomass $\left(\mathrm{g} \mathrm{m}^{-2}\right)$ within Florida Bay

drilla nucula ranged from $740.36 \pm$ 55.99 to $2596.74 \pm 432.74 \mathrm{ml} \mathrm{h}^{-1}$ (g tissue dry $w t)^{-1}$ and were significantly different among food types. Grazing rates on $S$. elongatus were significantly greater than those on the dinoflagellate $P$. hoffmanianum or the diatom C. choctawhatcheeana, but not for the mixed phytoplankton treatment. Filtration rates were also significantly greater for the mixed treatment and $P$. hoffmanianum than for $C$. choctawhatcheeana.

In addition to significant grazing rate differences exhibited by the same sponge species among different algal food treatments, significant differences within treatment grazing rates among the sponge species were observed (Fig. 5). Chondrilla nucula had significantly higher grazing rates than other

main effects, revealed strong significant differences for each main effect ( $p<0.001)$, as well as a strong interaction between the main effects $(p<0.001)$ (Table 2$)$. Therefore, Tukey's multiple comparison test with unequal sample sizes was used to compare means of one factor separately at each level of the other factor (and vice versa) in order to interpret the interaction (Underwood 1997).

Filtration rates of Spheciospongia vesparia ranged from $138.81 \pm 30.17$ to $228.50 \pm 41.48 \mathrm{ml} \mathrm{h}^{-1}$ (g tissue dry $w)^{-1}($ mean \pm SD) among the different treatments; however, Tukey's multiple comparison revealed no significant differences among phytoplankton types. Grazing rates of Ircinia sp. ranged from $144.78 \pm 17.97$ to $320.47 \pm 174.53 \mathrm{ml} \mathrm{h}^{-1}$ (g tissue dry wt $)^{-1}$ among different phytoplankton food sources. Again, there were no significant filtration rate differences among treatments. Tedania ignis grazing rates ranged from $70.94 \pm$ 12.63 to $2545.88 \pm 273.97 \mathrm{ml} \mathrm{h}^{-1}$ (g tissue dry wt $)^{-1}$ and were significantly different among food sources. Filtration rates of T. ignis were significantly higher for the mixed food treatment than for all other phytoplankton treatments. In addition, filtration rates of the dinoflagellate Prorocentrum hoffmanianum were significantly greater than those of the cyanobacteria Synechococcus elongatus. Cinachyra alloclada grazing rates ranged from $53.53 \pm$ 11.45 to $246.70 \pm 18.60 \mathrm{ml} \mathrm{h}^{-1}$ (g tissue dry $\mathrm{wt})^{-1}$. Filtration rates of the diatom Cyclotella choctawhatcheeana were significantly lower than those of the other 3 treatments. Finally, grazing rates of Chon- sponge species on the Synechococcus elongatus, Cyclotella choctawhatcheeana, and Prorocentrum hoffmanianum treatments, while both $C$. nucula and Tedania ignis had significantly higher filtration rates than the other sponge species on the mixed phytoplankton treatment.

Both the chl $a$ and particle data demonstrated that all of the sponge species were able to consume all 3 algal food sources. Additionally, particle data were used to determine if the different sponge species preferred different sized particles. Using the mixed phytoplankton grazing treatment, size preference was assessed by breaking the size-frequency histogram into bins and determining the change in particle density over the course of the experiment. Of the 5 sponge species used, only Ircinia sp. exhibited size particle preference, consuming significantly more particles $<10 \mu \mathrm{m}$ for the nonphycoerythrin-containing

Table 1. Average sponge filtration rates of dominant sponge species in Florida Bay and reported for other sponges elsewhere

\begin{tabular}{|lcc|}
\hline Sponge species & $\begin{array}{c}\text { Filtration rate } \\
\mathrm{ml} \mathrm{h}^{-1}(\mathrm{~g} \text { tissue dry wt) }\end{array}$ & Source \\
\hline Spheciospongia vesparia & 147 & This study \\
Ircinia sp. & 207 & This study \\
Tedania ignis & 1597 & This study \\
Cinachyra alloclada & 191 & This study \\
Chondrilla nucula & 2105 & This study \\
Niphates erecta & 141 & This study \\
Dysida avara & $104-2046$ & Ribes et al. (1999) \\
Spongilla lacustris & 3180 & Frost (1978) \\
Haliclona anonyma & 5604 & Stuart \& Klumpp (1984) \\
Haliclona urceolus & 1806 & Riisgard et al. (1993) \\
\hline
\end{tabular}




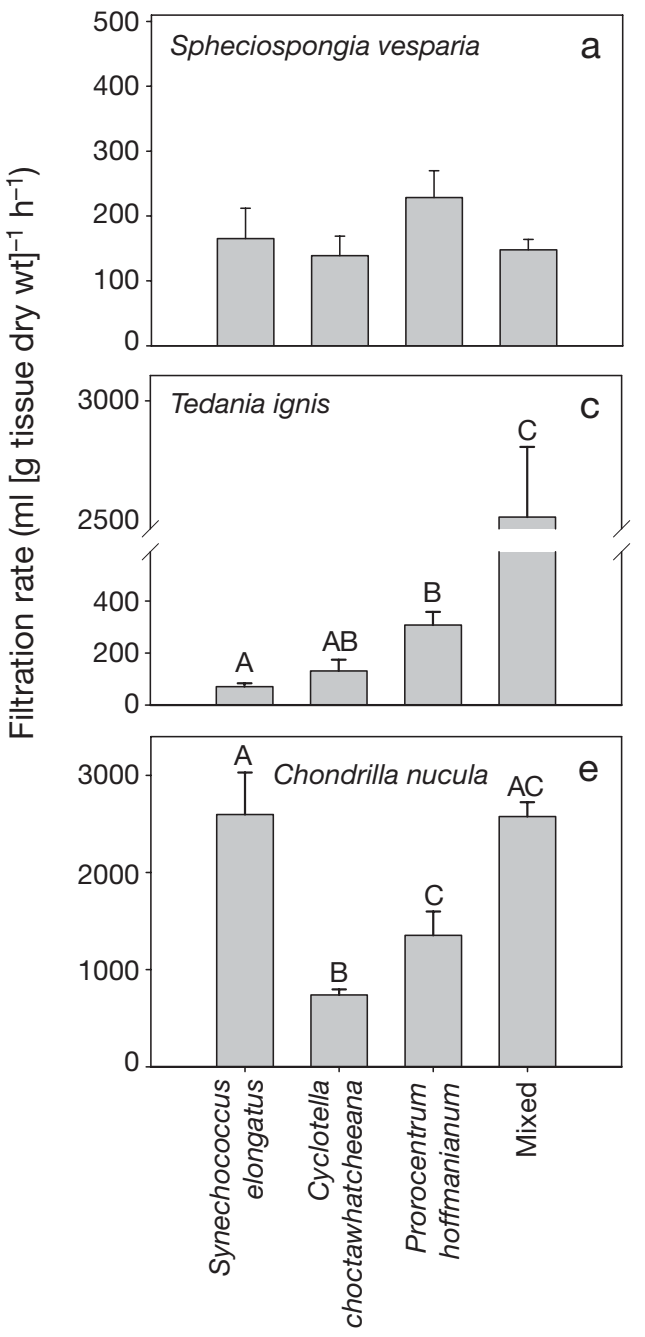

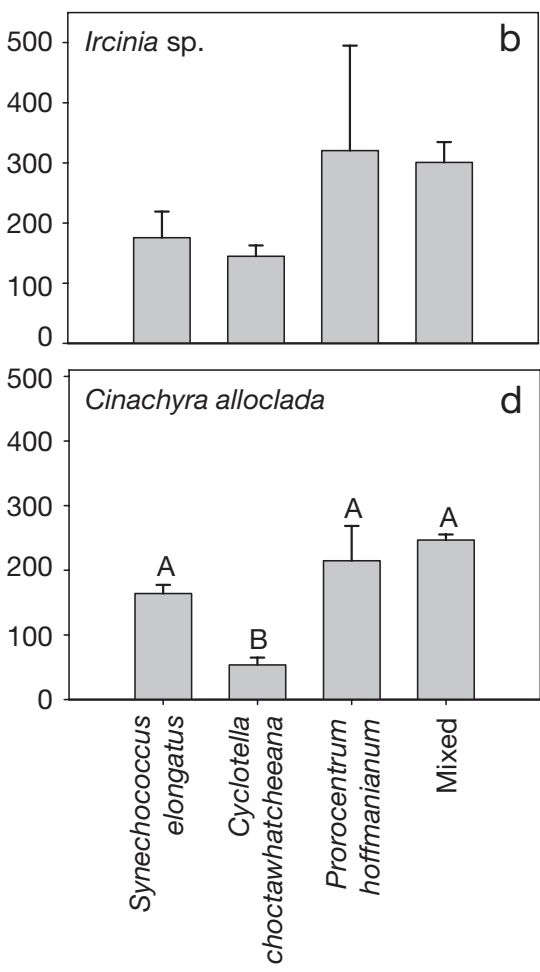

Fig. 4. Dominant sponges of Florida Bay. Filtration rates of each sponge species versus algal treatment in laboratory grazing experiments. (a) S. vesparia, (b) Ircinia sp., (c) T. ignis, (d) C. alloclada, (e) C. nucula. Error bars: SD; different letters above bars indicate significant differences between filtration rates (Tukey's multiple comparisons test, $\mathrm{p}=0.05$ )

\section{DISCUSSION}

The primary objective of this study was to experimentally evaluate the potential for suspension feeding sponges to control nuisance phytoplankton blooms within Florida Bay, prior to the large sponge die-off event (e.g. 1991). To achieve this objective, we determined the extent and biomass of the surviving sponge community in the different basins of Florida Bay. The survey demonstrated that sponges were still ubiquitous (Fig. 3). Once an estimate of the density and biomass of the sponge community was obtained, the grazing experiment was conducted to determine the water-processing abilities of the 5 dominant sponges in Florida Bay. This experiment ascertained that all 3 cultures (Synechococcus elongatus, Cyclotella choctawhatcheeana and Prorocentrum hoffmanianum), which ranged in cell length from 2 to $48 \mu \mathrm{m}$, were able to be grazed by the 5 dominant sponges of Florida Bay and that the filtration rates determined by the grazing experiment were similar to those reported for other sponges in the literature (Table 1). In addition, the filtra-

nanoplankton ( $p=0.02$ ). There was no significant difference among sponge species for the consumption of particles $<10 \mu \mathrm{m}$ for either the phycoerythrin-containing cyanobacterium Synechococcus elongatus or nonphycoerythrin-containing nanoplankton (Fig. 6).

\section{In situ grazing experiment}

The field-generated grazing rates of Spheciospongia vesparia were similar to those observed for the mixed phytoplankton treatment in the laboratory grazing experiment, $148 \pm 47.2 \mathrm{ml} \mathrm{h}^{-1}$ (g tissue dry $\mathrm{wt}^{-1}$ ) and $146 \pm 27.8 \mathrm{ml} \mathrm{h}^{-1}$ (g tissue dry $\left.\mathrm{wt}^{-1}\right)$, respectively. However, the phytoplankton were quickly consumed from within the chambers. After $60 \mathrm{~min}$, the decrease in chl a levels plateaued (Fig. 7). This was assumed to be a result of the food concentration falling below a threshold density. tion rates of Spheciospongia vesparia in the field were similar to those recorded in the laboratory experiment.

Having obtained the basin-specific density and biomass of the current sponge community and the filtration rates of the dominant sponges, it was possible to address whether the system-wide trophic dysfunction-a consequence of the documented sponge die-off (60 to $100 \%$ mortality across Florida Bay) (Butler et al. 1994, Stevely \& Sweat 1998)-has potentially contributed to the location and magnitude of the

Table 2. ANOVA results $(5 \times 4$ Model I) for sponge grazing experiment

\begin{tabular}{|lccccc|}
\hline Source & df & Type III SS & MS & $F$ & $\mathrm{p}>F$ \\
\hline Sponge (S) & 4 & 10.99 & 2.75 & 47.28 & $<0.001$ \\
Algae (A) & 3 & 2.21 & 0.74 & 12.66 & $<0.001$ \\
S $\times$ A & 12 & 3.44 & 0.29 & 4.935 & $<0.001$ \\
Error & 51 & 2.96 & 0.06 & & \\
Total & 71 & 429.95 & & & \\
\hline
\end{tabular}



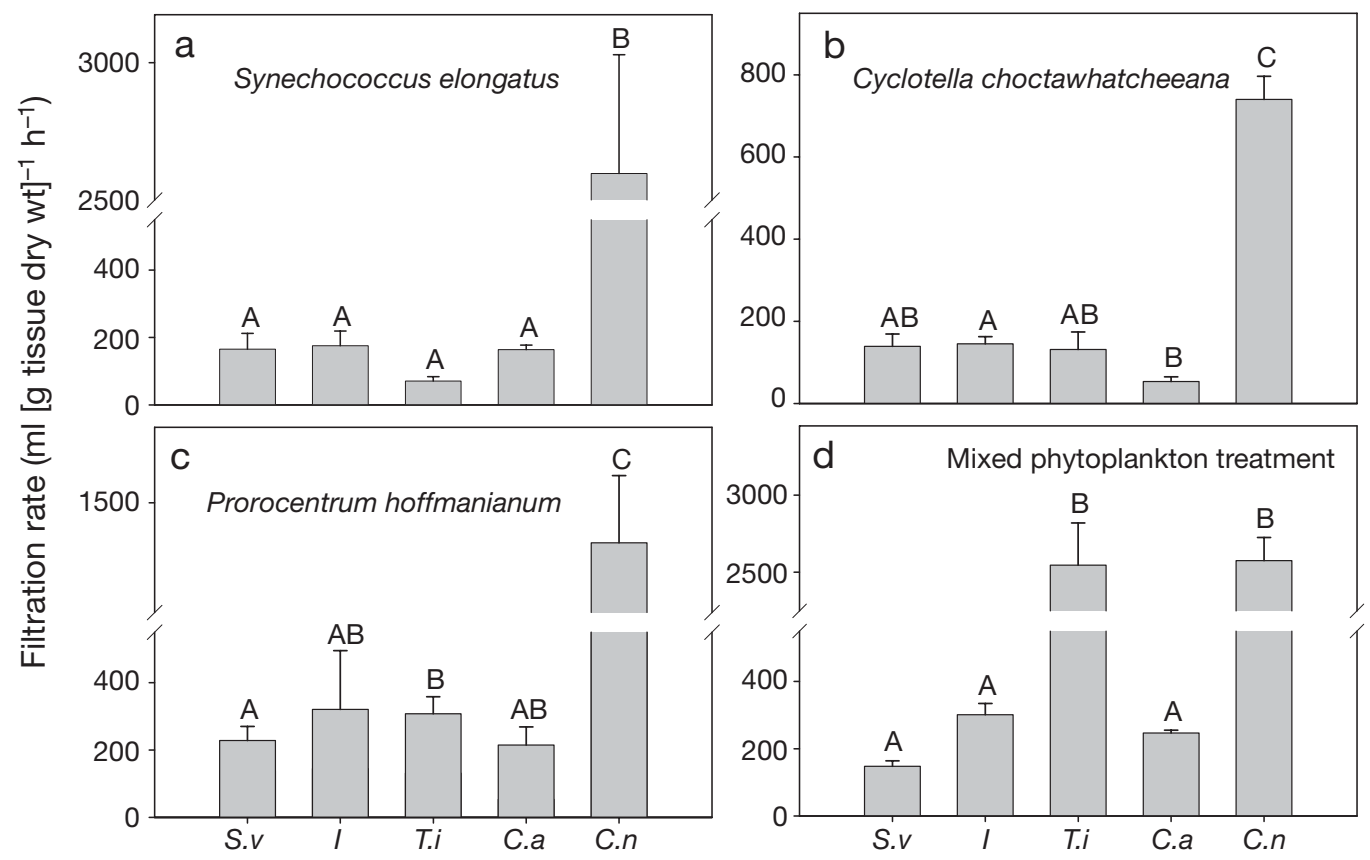

Fig. 5. Algal treatments: filtration rates by dominant sponges of Florida Bay-Spheciospongia vesparia (S.v), Ircinia sp. (I), Tedania ignis (T.i), Cinachyra alloclada (C.a), and Chondrilla nucula (C.n). Algal treatments are (a) S. elongatus, (b) C. choctawhatcheeana, (c) P. hoffmanianum, (d) mixed phytoplankton treatment. Error bars: SD; different letters above bars indicate significant differences between filtration rates (Tukey's multiple comparisons test, $\mathrm{p}=0.05$ )

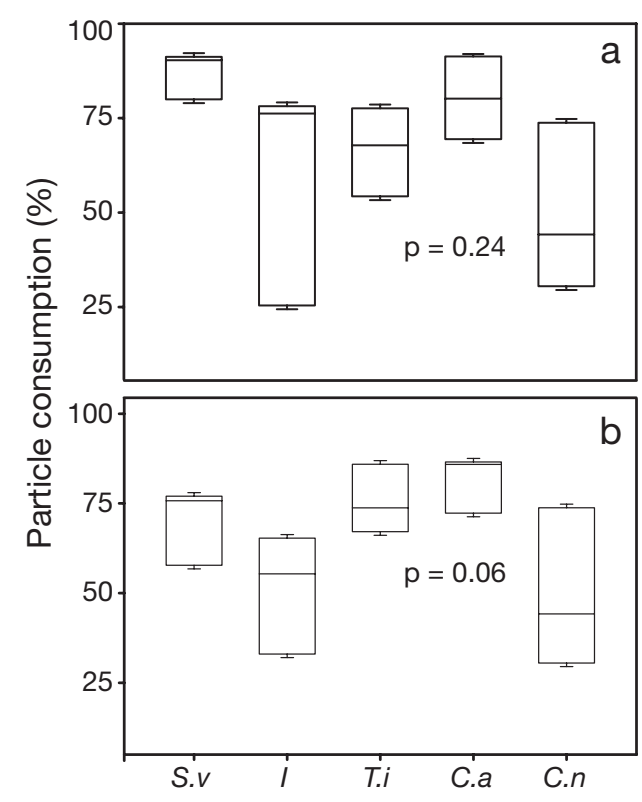

Fig. 6. Percent particles $<10 \mu \mathrm{m}$ consumed by 5 dominant sponge species - Spheciospongia vesparia (S.v), Ircinia sp. (I), Tedania ignis (T.i), Cinachyra alloclada (C.a), and Chondrilla nucula (C.n) - during mixed phytoplankton treatments. (A) Consumption of phycoerythrin-containing cyanobacteria, (B) consumption of non-phycoerythrin containing nanoplankton. $\mathrm{n}=4$ for each sponge species and each phytoplankton food treatment; lines within box-plots show median values; p-values represent differences in change in particle consumption between sponges; error bars: SD persistent blooms recurring in Florida Bay. To estimate the impact of the mass sponge mortality event on the system-wide filtration rate of Florida Bay, we combined estimates of the current sponge biomass and laboratory and in situ sponge filtration rates with estimates of the mean volumes of the sub-basins of Florida Bay determined from the Flux Accounting and Tidal Hydrology on the Ocean Margin (FATHOM) model for Florida Bay (Nuttle et al. 2000). The measured biomasses and water-processing abilities were used for the 5 dominant sponges, while the average filtration rate of the sponges used in the grazing experiment was used for the remainder of the sponge community.

Several assumptions were made to calculate the preand post-sponge die-off system-wide filtration rates of the sponge community within Florida Bay: (1) that other sponges in Florida Bay have the same filtering capacity as those obtained for the 5 dominant sponge species in our laboratory studies; (2) that hydrodynamic conditions allow the sponge community access to the entire water column; (3) that filtration rates of the sponges are constant; (4) that no other gain or loss functions associated with plankton populations exist; (5) that sponge abundance at our sites within each basin can be extrapolated to the entire basin defined by the FATHOM model; and (6) that every basin where sponge mortality was observed experienced a loss of $60 \%$ of the sponge community. 


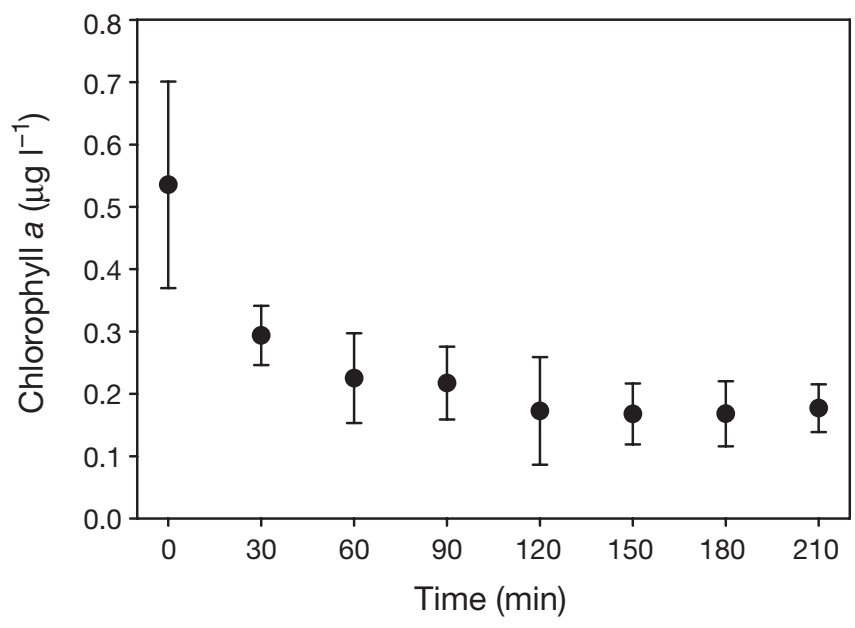

Fig. 7. Change in chl a concentration $\left(\mu g \mathrm{l}^{-1}\right)$ within in situ grazing chambers over time. Error bars: SD

Some of these assumptions are more easily justified than others. Because the 5 dominant sponges composed approximately $90 \%$ of the sponge biomass collected in the sponge survey, use of the mean filtration rate of these sponges for the remaining $10 \%$ of the sponge community biomass seems logical. As Florida Bay is a broad, shallow (approximately $2 \mathrm{~m}$ ) estuarine lagoon with distinct compartmentalisation by partially submerged banks and multiple islands, the assumption that there exists a partial isolaton of water masses in subregions of Florida Bay appears tenable. In addition, the shallow nature of the bay and the dominance of wind-driven circulation and lack of density stratification also suggest that the entire water column is available to the sponge community for grazing. However, the assumptions that filtration rates are constant, that there are no other loss or gain functions associated with the phytoplankton community, that sponge biomasses at the survey sites can be extrapolated to entire basins as defined by the FATHOM model, and that every basin where sponge mortality was observed experienced a $60 \%$ loss of the sponge community are not trivial assumptions, and require that the conclusions of these calculations be viewed with caution.

With these assumptions, the time required to filter the entire water column through the sponge community for each of the 45 individual Florida Bay basins before and after the sponge mass mortality event was calculated. The bay was then partitioned into 4 regions based on previous water quality modeling studies (Fourqurean et al. 1993, Phlips \& Badylak 1996). The average time for the entire water column to be filtered through each region's sponge community was calculated (Fig. 8). According to our simplistic model, the sponge filtering capacity of Florida Bay's north-eastern region was unaffected by the sponge mortality event. In contrast, the western region experienced an increase in system filtration time of $6 \mathrm{~d}$, whereas the southern region increased its filtration time by only $3 \mathrm{~d}$. However, the central region, which was the area of Florida Bay that was most affected by the sponge mortality event, was calculated to have increased its average system filtration time by $12 \mathrm{~d}$. According to our study, the area of Florida Bay that was impacted the most by the decrease in the sponge community is also the region experiencing the recurring phytoplankton blooms (Phlips \& Badylak 1996, Boyer et al. 1997). In this region, we calculated that prior to the die-off the sponge community could filter the water column every $3 \mathrm{~d}$. In contrast, it would now take $15 \mathrm{~d}$ for the surviving sponge community to do the same. Although this is a simplistic correlative attempt to determine the impact of sponge grazing in Florida Bay, it provides a strong justification for considering these organisms' ecological importance in controlling phytoplankton biomass in the water column.

This study implies that the current blooms occurring within the central region of Florida Bay may be accounted for by the loss of the dominant suspension feeder, rather than by invoking the need for a new addition of nutrients. One could predict that as the system recovers from the sponge die-off, the suspen-

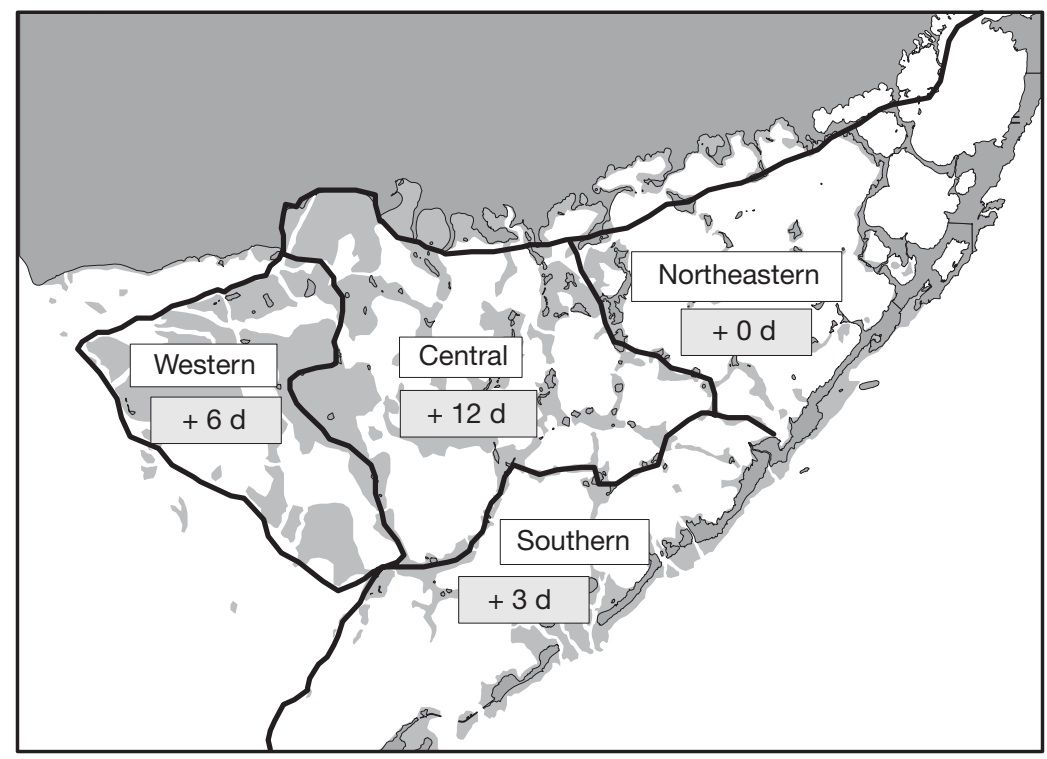

Fig. 8. Calculated average change in time required for the sponge community to filter the water column in each region of Florida Bay subsequent to the sponge mortality event 
sion grazing community will once again be able to control the phytoplankton communities and thus prevent bloom conditions within the central part of Florida Bay. However, the same regions that experience the persistent phytoplankton blooms and are most affected by the loss of the sponge community are also the regions that experience the greatest variation in salinity resulting from precipitation and evaporation. Since marine sponges are very sensitive to lower or greatly variable salinities, one could expect that the marine sponge communities may not recover quickly in this area.

The rapid environmental changes that have occurred within Florida Bay over the last decade have evoked a general concern for the state of the ecosystem. One major issue of concern is the decrease in water clarity in the western and central regions of Florida Bay. The western region of Florida Bay experienced a 4-fold decrease in water clarity from 1991 to 1996, while water clarity decreased by a factor of 20 in the central region (Boyer et al. 1999). This may have had substantial consequences for the benthic plant communities of Florida Bay. For example, seagrass productivity is limited primarily by nutrient and light availability. Recent observations of extensive die-off of seagrasses in Florida Bay have led to a number of alternate hypotheses on the causal factors involved, including the possible role of light limitation (Hall et al. 1999). The importance of light availability in controlling the maximum depth of seagrass colonization in other aquatic ecosystems is well established (Duarte 1991). Based on the regression relationships developed by Duarte (1991), light extinction coefficients in a number of basins within Florida Bay showed values high enough to theoretically preclude successful survival of seagrasses (Phlips et al. 1995). The recent proliferation of phytoplankton blooms in the north-central region of Florida Bay has contributed to the reduction of light availability for benthic plant production, as indicated by the substantial contribution of phytoplankton to total light attenuation (Phlips et al. 1995). Therefore, large abundances of sponges may play a significant role in reducing the shading effects of phytoplankton blooms and, in turn, in increasing light availability to benthic plant communities. Thus, the loss of these organisms may have cascading effects on the associated seagrass community of Florida Bay.

Acknowledgements. Many people provided field and laboratory support, including S. Escorcia, L. Rutten, C. Rose, S. Meeha, K. Cunniff and B. L. Peterson. Funding for this project was provided by grant SI2000-29 awarded to B.J.P. and J.W.F. from the Florida SeaGrant, and by a Tropical Biology PostDoctoral Fellowship award to B.J.P. from Florida International University. This project is contribution no. 115 of the Tropical Biology Program at Florida International University, contribu- tion no. 338 of the Southeast Environmental Research Center, and contribution 1325 of the Marine Sciences Research Center at Stony Brook University.

\section{LITERATURE CITED}

Boesch DF, Armstrong NE, D'Elia CF, Maynard NG, Paerl HW, Williams SL (1993) Deterioration of the Florida Bay ecosystem: an evaluation of the scientific evidence. Florida Bay Interagency Working Group, Key Largo, FL

Borum J, Pedersen O, Greve TM, Frankovich TA, Zieman JC, Fourqurean JW, Madden CJ (2005) The potential role of plant oxygen and sulfide dynamics in die-off events of the tropical seagrass, Thalassia testudinum. J Ecol 93:148-158

Boyer JN, Fourqurean JW, Jones RD (1997) Spatial characterization of water quality in Florida Bay and Whitewater Bay by multivariate analyses: zones of similar influence. Estuaries 20:743-758

Boyer JN, Fourqurean JW, Jones RD (1999) Seasonal and long-term trends in water quality of Florida Bay (1989-1997). Estuaries 22:417-430

Butler MJ, Herrnkind WF, Hunt JH (1994) Sponge mass mortality and Hurricane Andrew: catastrophe for juvenile spiny lobsters in south Florida? Bull Mar Sci 54:1073

Butler MJ, Hunt JH, Herrnkind WF, Childress MJ and 5 others (1995) Cascading disturbances in Florida Bay, USA: cyanobacterial blooms, sponge mortality, and implications for juvenile spiny lobsters Panulirus argus. Mar Ecol Prog Ser 129:119-125

Dame R, Dankers N, Prins T, Jongsma H, Smaal A (1991) The influence of mussel beds on nutrients in the Western Wadden Sea and Eastern Scheldt estuaries. Estuaries 14:130-138

Doering PH, Oviatt CA (1986) Application of filtration rate models to field populations of bivalves: an assessment using experimental mecocosms. Mar Ecol Prog Ser 31: 265-275

Duarte CM (1991) Seagrass depth limits. Aquat Bot 40: 363-377

Fourqurean JW, Robblee MB (1999) Florida Bay: a history of recent ecological changes. Estuaries 22:345-357

Fourqurean JW, Jones RD, Zieman JC (1993) Processes influencing water column nutrient characteristics and phosphorus limitation of phytoplankton biomass in Florida Bay, FL, USA: inferences from spatial distributions. Estuar Coast Shelf Sci 36:295-314

Frost TM (1978) In situ measurements of clearance rates for the freshwater sponge Spongilla lacustris. Limnol Oceanogr 23:1034-1039

Griffiths CL, Griffiths RJ (1987) Bivalvia. In: Pandian TJ, Vernberg FJ (eds) Animal energetics, Vol 2. Academic Press, London, p 1-88

Hall MO, Durako MJ, Fourqurean JW, Zieman JC (1999) Decadal changes in seagrass distribution and abundance in Florida Bay. Estuaries 22:445-459

Lapointe BE (2004) Anthropogenic nutrient enrichment of seagrass and coral reef communities in the Lower Florida Keys: discrimination of local versus regional nitrogen sources. J Exp Mar Biol Ecol 308:23-58

Lavrentyev PJ, Bootsma HA, Johengen TH, Cavaletto JF, Gardner WS (1998) Microbial plankton response to resource limitation: insights from the community structure and seston stoichiometry in Florida Bay, USA. Mar Ecol Prog Ser 165:45-57

Lynch TC, Phlips EJ (2000) Filtration of the bloom-forming cyanobacteria Synechococcus by three sponge species from Florida Bay, USA. Bull Mar Sci 67:923-936 
Mitsui A, Rosner D, Goodman A, Reyes-Vasquez G (1989) Hemolytic toxins in marine cyanobacterium Synechococcus sp. In: Okaichi T, Anderson M, Nemoto T (eds) Red tides: biology, environmental science, and toxicology. Elsvier, New York, p 367-370

Nuttle WK, Fourqurean JW, Cosby BJ, Zieman JC, Robblee MB (2000) Influence of net freshwater supply on salinity in Florida Bay. Water Resour Res 36:1805-1822

Officer CB, Smayda TJ, Mann R (1982) Benthic filter feeding: a natural eutrophication control. Mar Ecol Prog Ser 9: 203-210

Peters EC (1993) Diseases of other invertebrate phyla: Porifera, Cnidaria, Ctenophore, Annelida, Echinodermata. In: Couch JA, Fournie JW (eds) Pathobiology of marine and estuary organisms. CRC Press, Boca Raton, FL, p 393-449

Phlips EJ, Badylak S (1996) Spatial variability in phytoplankton standing crop and composition in a shallow inner-shelf lagoon, Florida Bay, Florida. Bull Mar Sci 58:203-216

Phlips EJ, Lynch TC, Badylak S (1995) Chlorophyll a, tripton, color, and light availability in a shallow tropical innershelf lagoon, Florida Bay, USA. Mar Ecol Prog Ser 127: 223-234

Phlips EJ, Badylak S, Lynch TC (1999) Blooms of the picoplanktonic cyanobacterium Synechococcus in Florida Bay, a tropical inner-shelf lagoon. Limnol Oceanogr 44:1166-1175

Pile AJ, Patterson WP, Witman JD (1996) In situ grazing on plankton $<10 \mu \mathrm{m}$ by the boreal sponge Mycale lingua. Mar Ecol Prog Ser 141:95-102

Pile AJ, Patterson MR, Savarese M, Chernykh VI, Failkov VA (1997) Trophic effects of sponge feeding within Lake

Editorial responsibility: Kenneth Heck (Contributing Editor), Dauphin Island, Alabama, USA
Baikal's littoral zone. 2. Sponge abundance, diet, feeding efficiency, and carbon flux. Limnol Oceanogr 42:178-184

Reiswig HM (1971) Particle feeding in natural population of three marine demosponges. Biol Bull (Woods Hole) 141: 568-591

Ribes M, Coma R, Gili J (1999) Natural diet and grazing rate of the temperate sponge Dysidea avara (Demospongiae, Dendroceratida) throughout an annual cycle. Mar Ecol Prog Ser 176:179-190

Riisgard HU, Thomassen S, Jakobsen H, Weeks JM, Larsen PS (1993) Suspension-feeding in marine sponges Halichondria panicea and Haliclona urceolus: effects of temperature on filtration-rate and energy-cost of pumping. Mar Ecol Prog Ser 96:177-188

Robblee MB, DiDomenico WJ (1991) Seagrass dieoff threatens ecology of Florida Bay. Park Sci 11:21-22

Stevely JM, Sweat DE (1998) Survey of recovery of Florida Keys sponge populations following a widespread sponge mortality. Report No. MR252, Florida Sea Grant Extension Program. Tallahassee, FL

Stuart V, Klumpp DW (1984) Evidence for food-resource partitioning by kelp-bed filter feeders. Mar Ecol Prog Ser 16: $27-37$

Underwood AJ (1997) Experiments in ecology: their logical design and interpretation using analysis of variance. Cambridge University Press, Cambridge

van de Vyver G, Vray B, Belaouane S, Toussaint D (1990) Efficiency and selectivity of micro-organism retention by Ephydatia fluviatilis. In: Rützler K (ed) New perspectives in sponge biology. Smithsonian Institute Press, Washington, DC, p 511-515

Submitted: February 9, 2005; Accepted: April 19, 2006 Proofs received from author(s): November 22, 2006 